\title{
Kepentingan Nasional Indonesia dalam Inisiasi ASEAN Maritime Forum (AMF)
}

\author{
Najamuddin Khairur Rijal \\ Universitas Muhammadiyah Malang
}

\begin{abstract}
The complexity of maritime security issues and problems in Southeast Asia became attention of ASEAN states which further encouraged the formation of the ASEAN Maritime Forum (AMF). AMF is a concept and proposal submitted by Indonesia and became one of the ASEAN Political-Security Community points. This research examines Indonesia's national interest in establishment of AMF. Based on national interest concept, there are three Indonesia's interest as focus of this study. First, Indonesia's interest as an Archipelago States and has a history of maritime glories. Second, maritime as sovereignty and the AMF existence as Indonesia efforts to maintaining maritime territorial integrity. Third, maritime economic as the third Indonesia's interests in propose of AMF establishment. In addition, this study also examine how the achievement of the Indonesia's national interests in AMF.
\end{abstract}

Keywords: $A M F$, archipelago states, Indonesia, national interest

\begin{abstract}
Abstrak
Kompleksitas isu dan masalah keamanan maritim di Asia Tenggara menjadi perhatian negara-negara ASEAN yang mendorong pembentukan ASEAN Maritime Forum (AMF). AMF adalah konsep yang diajukan oleh Indonesia dan menjadi salah satu poin dalam ASEAN Political-Security Community. Penelitian ini mengkaji mengenai kepentingan nasional Indonesia dalam pembentukan AMF. Berdasarkan konsep kepentingan nasional, ada tiga kepentingan Indonesia yang menjadi fokus penelitian ini. Pertama, kepentingan Indonesia sebagai Negara Kepulauan dan memiliki sejarah kejayaan maritim. Kedua, maritim adalah kedaulatan Indonesia dan eksistensi AMF sebagai upaya untuk menjaga integritas teritorial maritim tersebut. Ketiga, pentingnya ekonomi maritim menjadi kepentingan ketiga Indonesia dalam mengusulkan pembentukan AMF. Selain itu, penelitian ini juga melihat bagaimana pencapaian kepentingan nasional Indonesia dalam perjalanan AMF selama tujuh kali digelar.
\end{abstract}

Kata-kata kunci: AMF, negara kepulauan, Indonesia, kepentingan nasional 


\section{Pendahuluan}

Tulisan ini mengkaji mengenai kepentingan Indonesia dalam pembentukan ASEAN Maritime Forum (AMF). AMF sendiri merupakan forum dialog terkait isu-isu maritim dalam kerangka ASEAN. AMF yang pertama kali dilaksanakan pada tahun 2010 merupakan inisiasi dan usulan Indonesia. Usulan itu tidak dapat dilepaskan dari kepentingan nasional yang mendasari Indonesia dalam mengajukan pentingnya kehadiran sebuah forum dalam lingkup regional yang secara khusus untuk mendiskusikan berbagai isu dan masalah maritim di kawasan. Tulisan ini berargumen bahwa usulan Indonesia itu tidak terlepas dari adanya kepentingan Indonesia dalam hal penegasan identitas sebagai negara kepulauan, kepentingan dalam hal integritas teritorial laut, serta kepentingan ekonomi untuk memajukan kesejahteraan negara melalui pemanfaatan sumber daya kemaritiman.

Kehadiran AMF menjadi penting di ASEAN karena isu dan masalah maritim merupakan salah satu hal yang menjadi perhatian negara-negara di kawasan. Hal itu tidak terlepas dari dari kondisi geografis Asia Tenggara yang dikelilingi oleh laut. Luas wilayah laut Asia Tenggara bahkan mencapai $80 \%$ dari seluruh wilayahnya. Dengan laut yang luas itu, sekitar $60 \%$ masyarakat Asia Tenggara yang berjumlah sekitar 629 juta jiwa (data tahun 2015) mengandalkan sektor kelautan, perikanan, dan hal-hal yang berkaitan secara langsung maupun tidak langsung dengan laut sebagai tumpuan kehidupan ekonomi (Bradford 2005; Wibowo 2010). Selain itu, wilayah laut yang mengelilingi kawasan Asia Tenggara merupakan wilayah perairan yang memiliki peran penting dalam lalu lintas perdagangan internasional, salah satunya yaitu Selat Malaka.

Lebih dari itu, sebagai kawasan dengan maritim yang luas, keamanan maritim sekaligus menjadi masalah yang menjadi perhatian penting bagi negara-negara Asia Tenggara. Beberapa masalah itu antara lain seperti ancaman terhadap kedaulatan dan integritas teritorial, terutama bagi negara-negara kepulauan, karena konflik batas laut dan zona ekonomi eksklusif; kejahatan transnasional terorganisir (organize transnational crime) seperti terorisme di laut, penyelundupan senjata, penyelundupan narkotika, dan penyelundupan manusia; pembajakan, perompakan dan kejahatan bersenjata di laut; illegal fishing; dan ancaman keamanan maritim lainnya. Kompleksitas isu dan masalah keamanan maritim tersebut kemudian menjadi salah satu perhatian negara-negara Asia Tenggara yang memerlukan upaya bersama dalam kerangka organisasi regional ASEAN.

Konferensi Tingkat Tinggi (KTT) ASEAN di Bali yang mengesahkan Bali Concord II pada 7 Oktober 2003 menjadi salah satu penegasan ASEAN tentang pentingnya usaha untuk mengatasi beragam masalah di bidang maritim. Dalam Tabloid Diplomasi (2010), dijelaskan bahwa perhatian para pemimpin negara-negara ASEAN terhadap isu-isu maritim dipandang per- 
lu ditangani secara regional, holistik, terpadu dan komprehensif. Bali Concord II ini juga melahirkan ide pembentukan ASEAN Community, di mana salah satu pilarnya adalah ASEAN Political Security Community (ASPC). Dalam pilar APSC inilah, keamanan maritim menjadi salah satu tujuan yang hendak diwujudkan negara-negara ASEAN. Salah satu realisasinya adalah dengan lahirnya AMF pada tahun 2010.

Terkait APSC, perlu dipahami pula bahwa ide APSC yang menjadi pilar pertama dari ASEAN Community merupakan usulan Indonesia (Luhulima, 2008: 90). APSC merupakan konsep yang diajukan oleh Indonesia, di mana dalam KTT ASEAN di Bali pada tahun 2003, Indonesia mengajukan tujuh usul lainnya sebagai bagian dari APSC. Ketujuh usulan tersebut adalah: (1) mendorong pengamatan pemilu sukarela; (2) membentuk komisi perjuangan dan perlindungan hak perempuan dan anak; (3) memasukkan elemen memerangi korupsi dan pemajuan prinsip demokrasi; (4) menggagas pembentukan ASEAN Initiative for Peace and Reconciliation; (5) menggagas pembentukan AMF; (6) membentuk kerja sama penanganan illegal fishing; serta (7) menyusun instrumen ASEAN tentang hak pekerja migran.

Dalam hal gagasan tentang AMF, menurut Kementerian Luar Negeri (2010), pembentukan dan pelaksanaan AMF kemudian terwujud ketika Indonesia berhasil menggelar AMF ke-1 di Surabaya pada 28-29 Juli 2010. Untuk itu, menjadi menarik untuk mengkaji mengenai mengapa Indonesia mendorong pembentukan AMF. Alasan itu dapat dilihat sebagai bagian yang tidak terlepas dari kepentingan nasional Indonesia yang berkaitan dengan aspek kemaritiman. Tulisan ini kemudian berusaha untuk memaparkan dimensi dari kepentingan nasional yang dimiliki Indonesia dalam pembentukan AMF.

Kajian ini menjadi penting, karena berdasarkan kajian literatur penulis, belum ada pembahasan tentang kepentingan Indonesia sebagai inisiator dari AMF. Adapun penelitian tentang AMF umumnya berbicara tentang peran AMF dalam permasalahan ancaman keamanan maritim. Kartinawati (2013), misalnya, mengkaji tentang peran AMF dalam keamanan perairan di Asia Tenggara. Adapun Gaol (2017) membahas mengenai peran AMF dalam menjaga keamanan maritim di kawasan, secara khusus berfokus pada kasus perompakan di Selat Malaka. Keduanya berkesimpulan bahwa peran AMF adalah menjadi forum kerja sama untuk mencegah atau mengurangi intensitas konflik bagi anggotanya serta menjadi sarana perundingan untuk menghasilkan keputusan bersama yang saling menguntungkan, terutama terkait persoalan perairan di kawasan.

Tulisan ini selanjutnya dielaborasi ke dalam beberapa sub pembahasan. Pertama, diuraikan kerangka analisis tentang konsep kepentingan nasional. Kedua, penulis menjabarkan tentang gambaran umum AMF dimulai dari perjalanan sejarahnya hingga maksud dan tujuannya. Ketiga hing- 
ga kelima adalah uraian tentang kepentingan nasional Indonesia, secara berurut adalah kepentingan terkait identitas, integritas teritorial laut, dan aspek ekonomi. Kemudian, menegaskan bahwa pelaksanaan AMF pertama tahun 2010 merupakan realisasi semboyan politik luar negeri Indonesia di era SBY, yakni million friends, zero enemy. Terakhir, dibahas pula terkait bagaimana pencapaian kepentingan nasional Indonesia dalam AMF.

\section{Indonesia dan Kepentingan Nasional}

Politik luar negeri setiap negara selalu ditujukan untuk mencapai kepentingan nasionalnya. Menurut Plano dan Olton (1999) dalam Kamus Hubungan Internasional, setiap politik luar negeri dirancang untuk menjangkau tujuan nasional. Kepentingan nasional ini menjadi konsepsi yang vital bagi setiap negara sebab eksistensi sebuah negara pada hakikatnya adalah untuk mencapai kepentingan nasionalnya. Hans J. Morgenthau (2010) dalam bukunya yang berjudul Politics Among Nations mendefinisikan kepentingan nasional sebagai kemampuan minimum negara-bangsa dalam melindungi identitas fisik (wilayah, tanah, teritorial), identitas politik (rezim ekonomi politik), dan identitas kulturalnya (norma etnis, linguistik, sejarah) dari gangguan negara atau bangsa lain.

Sementara itu, Holsti (1987) dalam International Politic: A Framework Analysis menyatakan bahwa tujuan politik luar negeri suatu negara harus bersifat spesifik dan harus disesuaikan dengan kebutuhan negara atau kepentingan nasional. Holsti kemudian mengidentifikasi kepentingan nasional dalam tiga klasifikasi. Pertama adalah core values, yakni sesuatu yang dianggap paling vital bagi negara dan menyangkut eksistensi suatu negara, dalam hal ini adalah kedaulatan. Kedua adalah middle-range objectives, menyangkut kebutuhan mengembangkan atau meningkatkan perekonomian negara. Ketiga adalah long-range goals, yaitu kepentingan jangka panjang sebagai sesuatu yang bersifat ideal, misalnya keinginan mewujudkan perdamaian dan ketertiban dunia.

Adapun konsep kepentingan nasional menurut Jack C. Plano dan Roy Olton (1999: 7) diartikan sebagai perjuangan untuk mencapai kekuasaan dan mempertahankannya dengan cara menunjukkan aksi-aksi politik. Kepentingan nasional menurut Plano dan Olton (1999) terdiri dari elemen-elemen yang meliputi self-preservation (pertahanan diri), independence (kemerdekaan, kemandirian), territorial integrity (integritas wilayah), military security (keamanan militer), dan economic well-being (kesejahteraan ekonomi).

Definisi dan elemen kepentingan nasional yang dikemukakan oleh tiga akademisi di atas pada hakikatnya memiliki substansi yang sama. Berdasarkan pemahaman itu, tulisan ini hendak melihat bahwa setidaknya ada tiga hal utama yang menjadi kepentingan nasional Indonesia dalam 
pembentukan AMF. Pertama, kepentingan terkait identitas negara, yakni sebagai negara kepulauan. Kedua, kepentingan terkait integritas wilayah maritim yang sangat berkaitan dengan dimensi kedaulatan sebagai core values yang substansial bagi negara. Ketiga, berkaitan dengan kepentingan ekonomi maritim (economic well-being) yang menurut Holsti merupakan kepentingan jangka menengah suatu negara. Ketiganya kemudian dielaborasi dalam pembahasan tulisan ini.

\section{AMF: Sebuah Gambaran Umum}

Sebagaimana telah dikemukakan di awal, salah satu pilar dari ASEAN Community yang disepakati dalam Bali Concord II tahun 2003 adalah pilar politik-keamanan. Guna menindaklanjuti hasil dari Bali Concord II tersebut, dalam KTT ASEAN ke-10 di Vientiane tahun 2004, diadopsi Rencana Aksi (Plan of Action/PoA) dan Vientiane Action Program (VAP) yang meliputi kegiatan jangka menengah periode 2004-2010 untuk merealisasikan APSC. Salah satu poinnya adalah promosi kerja sama keamanan maritim ASEAN melalui pembentukan AMF. Kemudian, pada Konferensi Koordinasi Rencana Aksi Komunitas Keamanan ASEAN (ASEAN Security Community Plan of Action Coordinating Conference/ASCCO) yang digelar oleh Sekretariat ASEAN pada 4-5 September 2006, negara-negara ASEAN menyepakati percepatan pelaksanaan PoA tersebut. Dalam forum tersebut, usulan Indonesia untuk menggelar workshop tentang pembentukan AMF disetujui (Tabloid Diplomasi, 2010).

Selanjutnya, tindak lanjut Indonesia adalah melakukan Lokakarya Pembentukan AMF di Batam pada 7-8 September 2007. Hasil dari lokakarya tersebut berupa konsep pendirian AMF yang diajukan oleh Indonesia pada ASEAN Senior Officer Meeting (SOM) di Singapura pada tanggal 6-7 Mei 2008. Pada KTT ASEAN ke-14 di Cha-am Hua Hin, Vietnam, pada 1 Maret 2009, ASEAN mengadopsi cetak biru (blueprint) APSC di mana salah satu poin utamanya adalah pembentukan AMF sebagaimana konsep yang diajukan Indonesia. Konsep yang diusulkan Indonesia ini kemudian disepakati oleh semua negara anggota dengan memperhatikan saran dan pandangan negara-negara ASEAN dalam Brainstorming mengenai AMF yang dilaksanakan di Medan pada 25 November 2009 (Ayu, 2015: 158).

Pembentukan dan pelaksanaan AMF kemudian terwujud ketika Indonesia menggelar AMF ke-1 di Surabaya pada 28-29 Juli 2010. Adapun tujuan dari AMF antara lain adalah untuk (Tabloid Diplomasi, 2010): (a) mengembangkan kerja sama maritim melalui dialog dan konsultasi konstruktif mengenai isu-isu maritim; (b) mempromosikan dan mengembangkan pemahaman antara negara-negara ASEAN mengenai isu-isu maritim regional dan global; (c) upaya untuk berkontribusi dalam menciptakan Confidence Building Measures (CBM) dan Preventive Diplomacy (PD); (d) men- 
dorong kemampuan negara anggota ASEAN untuk mengelola masalah maritim melalui konsultasi tanpa mengganggu hak-hak, kedaulatan dan integritas teritorial; (e) melakukan penelitian kebijakan yang berorientasi pada masalah-masalah maritim regional serta mempromosikan pembangunan kapasitas, dan kerja sama dalam keamanan dan perlindungan lingkungan maritim.

Hingga tahun 2017, AMF telah dilaksanakan sebanyak tujuh kali. Setelah AMF ke-1 di Indonesia, Thailand menjadi tuan rumah pertemuan AMF ke-2 tahun 2011 di Pattaya. Kemudian, Filipina menjadi tuan rumah pertemuan AMF ke-3 tahun 2012 di Manila. Selanjutnya, pertemuan AMF ke-4 tahun 2013 digelar di Kuala Lumpur, Malaysia. Sedangkan pertemuan AMF ke-5 dilaksanakan di Da Nang, Vietnam tahun 2014. Pada tahun 2015, Indonesia kembali menjadi tuan rumah pada pertemuan AMF ke-6 di Manado. Adapun tahun 2016, AMF tidak terlaksana karena tidak ada negara ASEAN yang bersedia menjadi tuan rumah. Sehingga, untuk pertemuan AMF ke-7, disepakati dan dilaksanakan di Sekretariat ASEAN di Jakarta pada 6 Desember 2017. Pelaksanaan AMF ke-7 di Sekretariat ASEAN merupakan usulan Indonesia untuk menghindari tertundanya kembali pelaksanaan AMF (Kementerian Luar Negeri Indonesia, 2017). Pada pertemuan yang dipimpin oleh Indonesia tersebut, AMF ke-7 membahas mengenai penguatan kerja sama maritim di ASEAN serta sinergitas seluruh badan sektoral ASEAN dalam menangani isu-isu maritim (Sekretariat Nasional ASEAN-Indonesia, 2017).

Selama tujuh tahun dan tujuh kali pelaksanaan AMF, Indonesia telah menjadi tuan rumah sebanyak tiga kali, yakni pada AMF pertama tahun 2010, AMF keenam tahun 2015, dan AMF ketujuh tahun 2017. Hal ini sekaligus secara tersirat menunjukkan bahwa Indonesia sangat berkepentingan di AMF. Meskipun dalam Concept Paper AMF disebutkan bahwa agenda pembahasan dalam forum tersebut ditentukan oleh negara yang menjabat sebagai Ketua ASEAN saat itu, tetapi dalam praktiknya, agenda AMF lebih sering ditentukan oleh negara tuan rumah. Sehingga, agenda AMF cenderung akan merefleksikan kepentingan nasional negara yang menjadi tuan rumah (Masyarakat ASEAN, 2016). Terlepas dari itu, pembahasan selanjutnya mengurai mengenai kepentingan nasional apa saja yang mendasari Indonesia dalam menginisiasi dan mengawali pembentukan AMF.

\section{Indonesia sebagai Negara Kepulauan}

Indonesia adalah negara kepulauan (archipelogic state) terbesar di dunia, serta memiliki identitas sejarah sebagai bangsa yang pernah memiliki kejayaan maritim di masa lalu. Sebagai negara kepulauan, berdasarkan United Nations Convention on the Law of the Sea (UNCLOS) tahun 1982, Indonesia memiliki jumlah pulau sebanyak 17.508. Adapun garis pantai Indone- 
sia terbentang hingga 54.716 kilometer dan luas wilayah mencapai 1,9 juta mil persegi sekaligus negara yang memiliki garis pantai terluas di dunia setelah Kanada (Majalah Parlementaria, 2014).

Selain laut yang luas, posisi geografis Indonesia juga strategis karena berada di antara dua benua (benua Asia dan benua Australia) dan dua samudra (Samudra Hindia dan Samudra Pasifik), dan telah lama menjadi jalur utama pelayaran dan perdagangan dunia. Karena itu, dibanding negara-negara kepulauan yang dipisahkan atau dikelilingi oleh laut (insular) di Asia Tenggara, seperti Filipina, Malaysia, Brunei Darussalam, dan Singapura, dapat dikatakan bahwa Indonesia sangat berkepentingan terkait berbagai aspek yang berhubungan dengan laut.

Sebagai negara kepulauan, tonggak historis penegasan Indonesia menjadi negara kepulauan pasca kemerdekaan adalah diawali dengan lahirnya Deklarasi Juanda ${ }^{1}$ pada 13 Desember 1957 (Adisasmita, 2013) yang menyatakan: "Segala perairan di sekitar, di antara dan yang menghubungkan pulau-pulau yang termasuk dalam daratan Republik Indonesia adalah bagian dari wilayah daratan Indonesia dan dengan demikian merupakan bagian daripada perairan nasional yang berada di bawah kedaulatan Republik Indonesia." Deklarasi Juanda ini kemudian diajukan ke Konvensi Hukum Laut Internasional atau UNCLOS tahun 1958.

Butuh waktu selama 25 tahun dari 1958 sampai 1982 dalam tiga kali pertemuan UNCLOS hingga usulan Indonesia diterima. Pada 10 Desember 1982 dalam pertemuan UNCLOS III di Montego Bay, Jamaica, UNCLOS menerima dan mengesahkan usulan dalam Deklarasi Juanda, yang dikenal dengan Island Territory Principles. Island Territory Principles merupakan prinsip penentuan batas wilayah negara kepulauan (atau negara yang terdiri dari banyak pulau) (Adisasmita, 2013). UNCLOS $1982^{2}$ yang disebut juga

1 Lahirnya Deklarasi Juanda dilatar belakangi oleh masalah yang dihadapi Indonesia mengenai batas wilayah. Sesuai dengan standar internasional, wilayah perairan suatu negara ditetapkan sejauh 12 mil laut dari garis pantai. Bila ketentuan ini diterapkan dalam konteks Indonesia, maka ada banyak wilayah perairan yang tidak termasuk dalam wilayah kepulauan Indonesia dan pemerintah tidak memiliki kewenangan dan kedaulatan atas wilayah perairan itu. Perdana Menteri Ir. Juanda kemudian menyadari masalah itu hingga melahirkan pernyataan yang disebut sebagai Deklarasi Juanda. Juanda mengusulkan bahwa jarak 12 mil laut yang terjauh dari pulau-pulau yang terletak terluar, dan dihubungkan secara keseluruhan, merupakan wilayah kekuasaan negara Indonesia. Baca Rahardjo Adisasmita, (2013), Pembangunan Ekonomi Maritim, Yogyakarta: Graha Ilmu, hal. 17.

2 UNCLOS 1982 ini mengatur yurisdiksi maritim yang bisa diklaim oleh negara pantai (kepulauan) yang meliputi zona-zona, yaitu laut teritorial (12 mil laut), zona tambahan (24 mil laut), zona ekonomi eksklusif/ZEE (200 mil laut), dan landas kontinen (hingga 350 mil laut atau lebih). 
sebagai "a constitution of the ocean", sekaligus menegaskan bahwa Indonesia adalah negara kepulauan terbesar di dunia (Arsana dan Sumaryo, 2010 dalam Madu, 2010: 69). Konsekuensi yang diterima Indonesia adalah perairan yurisdiksi Indonesia mengalami pertambahan luas yang luar biasa, yaitu mencapai 5,8 juta kilometer persegi dari total 7,9 juta kilometer persegi wilayah Indonesia secara keseluruhan (Adisasmita, 2013).

Pemahaman sebagai negara kepulauan ini tidak terlepas pula dari kenyataan sejarah Indonesia sebagai bangsa yang pernah memiliki kejayaan maritim, sebelum akhirnya kolonialisme bangsa Eropa memutus kejayaan itu. Nenek moyang Indonesia adalah pelaut ulung. Karena itu, menurut Prasetia (2016), semboyan "Nenek Moyangku Seorang Pelaut" bukanlah sekadar semboyan nasionalisme. Kajian prasejarah membuktikan bahwa bangsa Indonesia lahir dari migrasi melalui laut selama ribuan tahun. Hal itu didukung dengan temuan situs prasejarah dan bukti arkeologis yang banyak ditemukan di berbagai wilayah (Limbong, 2015). Bukti prasejarah tersebut setidaknya menunjukkan bahwa nenek moyang bangsa Indonesia telah lama bersentuhan dengan laut dengan segala aspeknya.

Selain itu, dalam perjalanan sejarah peradaban Indonesia, dikenal dua kerajaan besar yang dicatat dalam sejarah sebagai kerajaan yang pernah berjaya di lautan dan sebagai penguasa maritim. Keduanya adalah kerajaan Sriwijaya dan Majapahit. Kerajaan Sriwijaya dan Majapahit dicatat dalam sejarah sebagai kerajaan yang besar dan dihormati karena kemampuannya memanfaatkan ruang geografis yang dimiliki dan dikuasainya. Sriwijaya dan Majapahit mampu menguasai pelabuhan-pelabuhan utama dan jalurjalur pelayaran yang menghubungkannya dengan seluruh wilayah Nusantara, dengan didukung oleh armada laut yang tangguh (Limbong, 2015).

Sriwijaya yang berpusat di Sumatera Selatan, pernah menguasai dan mengontrol jalur perdagangan di Selat Malaka, Selat Sunda, Laut China Selatan, Laut Jawa, dan Selat Karimata, bahkan memonopoli perdagangan dengan Cina. Sriwijaya yang telah ada sejak abad VII (638-1030 M) bahkan merupakan salah satu kerajaan yang pernah menjadi kerajaan maritim terbesar di Asia Tenggara sebelum akhirnya runtuh pada abad ke-14 (Limbong, 2015). Sementara Majapahit (1293-1525 M) yang berbasis di Jawa Timur sebagai penguasa Laut Jawa yang menjadi jalur pelayaran utama Selat Malaka hingga Maluku saat itu. Ekspansi wilayah menjadikan Majapahit memiliki wilayah yang luas hingga disegani di seluruh dunia. Dominasi kerajaan Sriwijaya dan Majapahit tersebut menjadikan Nusantara (Indonesia) pernah menjadi bangsa penguasa lautan.

Akan tetapi, menurut Salamah (2016), semenjak datangnya penjajahan Eropa, mulai dari Portugis, Spanyol, hingga terutama Belanda, kejayaan Indonesia atas laut dikuasai oleh penjajah sehingga jiwa bahari Indonesia mulai hilang. Para penjajah bangsa-bangsa Eropa memulai pen- 
jajahan dengan strategi menguasai daerah-daerah pinggiran (daerah pantai) terlebih dahulu sebelum kemudian memperkuat pendudukannya di wilayah-wilayah strategis. Portugis, misalnya, memulai dengan menguasai Malaka pada tahun 1511 di bawah pimpinan Alfonso d'Albuquereque, kemudian bisa menguasai Ternate dan Tidore dua tahun kemudian. Hal yang sama dilakukan Belanda. Cornellis de Houtman memulai ekspansi kolonial Belanda dengan mendarat di Banten pada tahun 1596. Kemudian, ekspedisi kedua di bawah pimpinan Jacob Van Neck dengan mendirikan Vereenigde Oosstindische Compagnie (VOC), sebagai cikal bakal penjajahan Belanda selama lebih dari tiga abad. Dengan menaklukkan seluruh wilayah Nusantara (Indonesia), aktivitas kemaritiman sepenuhnya di bahwa kekuasaan penjajah.

Perkembangan industrialisasi kemudian mendorong pemerintah Belanda melakukan kegiatan ekonomi yang berorientasi darat, sementara laut hanya menjadi sebuah kawasan penghubung antarwilayah. Tambahan pula, pada masa kolonial berlaku sistem tanam paksa. Sistem tanam paksa ini, menurut Limbong (2015: 84), praktis menghasilkan pergeseran kehidupan masyarakat dari kehidupan budaya bahari menjadi kehidupan budaya agraris. Alhasil, setelah Indonesia merdeka, masyarakat maupun pemerintah lebih berorientasi pada pengembangan pembangunan ekonomi darat dengan corak kehidupan masyarakat pada budaya agraris.

Karena itu, inisiasi pembentukan dan pelaksanaan AMF oleh Indonesia perlu dilihat sebagai upaya penegasan identitas sejarah bangsa Indonesia. Sebagai negara kepulauan, dapat dikatakan bahwa Indonesia yang paling berkepentingan terhadap laut. Kepentingan atas laut berusaha diwujudkan dengan adanya sebuah forum yang dapat menjadi sarana dialog negara-negara di kawasan untuk membahas berbagai ancaman terhadap keamanan maritim. Sebab, bicara soal ancaman keamanan maritim, maka Indonesia adalah negara yang paling banyak dan paling sering terancam dari adanya berbagai kejahatan berbasis laut. Hal itu tidak terlepas dari bentang laut Indonesia yang sedemikian luas sehingga tidak dapat dikontrol secara menyeluruh. Bentang laut yang luas itu juga berbatasan secara langsung dengan banyak negara sehingga turut berpengaruh terhadap integritas kedaulatan laut.

\section{Kepentingan Indonesia atas Kedaulatan Maritim}

Pembentukan AMF tidak terlepas pula dari tujuan Indonesia sebagai negara kepulauan untuk mencapai kepentingan nasional dengan menjaga kedaulatan maritim dan integritas teritorial laut dari segala ancaman. Indonesia memiliki batas laut dengan 10 negara, yakni India, Thailand, Malaysia, Singapura, Vietnam, Filipina, Palau, Papua Nugini, Timor-Leste dan Australia serta sekaligus batas darat dengan tiga negara yaitu Malaysia, 
Timor-Leste dan Papua Nugini (Kementerian Luar Negeri, 2011). Kompleksnya persoalan perbatasan mengakibatkan penetapan batas laut dan juga darat dengan beberapa negara tersebut belum sepenuhnya tuntas. Hal itu dapat dilihat antara lain dengan konflik terkait perbatasan laut antara Indonesia dengan Malaysia, Singapura, Thailand dan Vietnam yang mewarnai dinamika kerja sama ASEAN.

Indonesia dengan Malaysia belum menyelesaikan beberapa batas maritim di segmen Selat Malaka, Selat Singapura, Laut China Selatan, dan Laut Sulawesi. Dengan Singapura, Indonesia belum menyelesaikan batas laut wilayah di segmen Timur Selat Singapura. Adapun dengan Thailand, pemerintah Indonesia belum menyelesaikan batas Zona Ekonomi Eksklusif (ZEE). Sementara dengan Vietnam, belum menyelesaikan batas ZEE di Laut China Selatan. Begitu pula dengan Filipina terkait batas maritim dan klaim perairan. Karena itu, masalah penetapan batas wilayah merupakan salah satu prioritas utama pemerintah untuk menjamin keutuhan dan kesatuan wilayah NKRI. Dalam buku Diplomasi Indonesia 2010 (Kementerian Luar Negeri, 2011), disebutkan bahwa hingga tahun 2010, Indonesia telah menyelesaikan 16 perjanjian perbatasan laut Indonesia dengan negara tetangga, namun sisanya masih lebih banyak yang belum diselesaikan.

Dengan demikian, pembentukan AMF menjadi upaya Indonesia untuk mendudukkan persoalan teritorial laut itu dalam sebuah forum dialog yang melibatkan negara-negara Asia Tenggara. Forum itu sekaligus menegaskan usaha Indonesia untuk menyelesaikan berbagai sengketa dan klaim wilayah laut dengan tetangganya dengan cara damai, kerja sama, diplomasi, dan tanpa melibatkan kekuatan militeristik. Hal itu sebagaimana salah satu tujuan AMF adalah untuk menciptakan confidence building measures dan preventive diplomacy.

Penentuan perbatasan laut dengan negara-negara tetangga ini menjadi penting karena menyangkut aspek kedaulatan. Laut merupakan sebuah kedaulatan yang harus dipertahankan sebab merupakan harga diri dan kehormatan suatu bangsa (Prasetia, 2016). Menurut Holsti (1987), dalam konsep kepentingan nasional yang dikemukakan di awal, kedaulatan adalah kepentingan vital (cores) setiap negara. Selain kedaulatan, laut menyimpan banyak kepentingan bagi negara, baik kepentingan geopolitik, geostrategis, maupun geoekonomi. Karena itu, sebagai negara kepulauan, Indonesia sangat berkepentingan dengan maritim. Maritim di sini dimaknai sebagai segala aktivitas/kegiatan yang dilakukan dan berkaitan dengan laut, termasuk interaksi antara sumber daya manusia dengan berbagai kegiatan di laut, pemanfaatan sumber daya kelautan, industri berbasis kelautan, transportasi laut, pemasaran hasil-hasil laut, serta perdagangan di laut (Adisasmita, 2013). 
Sekaitan dengan itu, maka aspek ekonomi kelautan menjadi kepentingan penting bagi Indonesia sebagai negara memiliki laut yang luas. Konsepsi negara maritim (maritime state) ini mengharuskan Indonesia dapat mengambil manfaat ekonomi, politik, keamanan dan pertahanan, serta sosial-budaya dari kondisi geografis sebagai negara kepulauan. Karena itu, penguasaan atas teritorial laut yang mengelilingi Indonesia juga sangat berkaitan dengan kepentingan ekonomi.

\section{Kepentingan Ekonomi Maritim}

Selain aspek kedaulatan, pembentukan AMF perlu juga dilihat sebagai salah satu upaya Indonesia untuk mencapai kepentingan terkait dengan economic well-being. Wilayah laut Indonesia yang meliputi laut teritorial, zona tambahan (contiguous zona), ZEE, hingga landas kontinen (continental shelf) memiliki kekayaan yang melimpah. Laut Indonesia memiliki potensi ekonomi yang besar di berbagai sektor seperti, sektor perikanan, pariwisata bahari, pertambangan laut, industri maritim, perhubungan laut, dan jasa kelautan. Harus diakui bahwa potensi kelautan selama ini memberikan sumbangan yang besar bagi pembangunan nasional.

Menurut Kusumastanto (2013), sumbangan dari sumber daya kelautan tersebut, antara lain berupa penyediaan bahan kebutuhan dasar, peningkatan pendapatan masyarakat, kesempatan kerja, perolehan devisa dan pembangunan daerah. Hal itu didukung pula oleh potensi sumber daya manusia, di mana penyebaran penduduk Indonesia sekitar 60 juta lebih bermukim di 13.000 desa di wilayah pantai, dengan $60 \%$ kota-kota di Indonesia berada di zona pesisir (Limbong, 2015). Sehingga, kegiatan perekonomian berdimensi kelautan memiliki makna yang strategis.

Dengan lautan yang luas, Indonesia menyimpan $14 \%$ dari total terumbu karang yang ada di dunia. Selain itu, diperkirakan lebih dari 2.500 jenis ikan dan 500 karang hidup di laut Indonesia. Indonesia memiliki Segitiga Terumbu Karang yang disebut juga sebagai hutan Amazon di bahwa laut (Amazon of the seas) yang mencakup wilayah perairan tengah dan timur Indonesia (Limbong, 2015). Karenanya, dengan luas laut 5,8 juta kilometer persegi (berdasarkan UNCLOS 1982), Indonesia menyimpan potensi sumber daya hayati dan non hayati yang melimpah di laut. Dari segi pariwisata, Indonesia memiliki tempat pariwisata laut yang kaya.

Lebih lanjut, Lembaga Ilmu Pengetahuan Indonesia (LIPI) dalam penelitiannya, sebagaimana dikutip Limbong (2015), menemukan bahwa setidaknya terdapat 529 biota di perairan laut selatan Jawa dan barat Sumatera. Biota tersebut terdiri dari 415 jenis ikan, 68 jenis udang dan kepiting, serta 46 lainnya jenis cumi-cumi. Biota tersebut berpotensi untuk mendukung ketahanan pangan melalui diversifikasi produk pangan. Laut Indonesia juga memiliki sekitar 13 dari 20 jenis lamun dunia, sebanyak 682 
spesies rumput laut, lebih dari 2.500 spesies moluska, 1.502 krustasea, dan 745 spesies ekonodermata. Kekayaan itu belum termasuk pertambangan dan energi, berupa minyak dan gas bumi yang dikandung oleh kawasan laut Indonesia.

Dalam konteks internasional, potensi ekonomi maritim Indonesia tidak terlepas dari posisi geostrategis Indonesia yang menjadi jalur perhubungan laut dunia atau "sea lanes of communications". Jalur ini atau yang disebut dengan chokepoints perdagangan internasional terdiri dari tujuh, dan empat di antaranya dimiliki oleh Indonesia. Empat chokepoints tersebut adalah Selat Malaka, Selat Sunda, Selat Lombok, dan Selat Makassar. ${ }^{3}$ Selat Malaka sendiri merupakan selat terpenting dalam perdagangan minyak dunia dengan sepertiga perdagangan dunia dan setengah produksi minyak dunia melalui jalur ini setiap tahun. Bahkan Jepang dan Cina sebagai motor penting perdagangan di Asia dan dunia bergantung pada selat ini untuk mengimpor lebih dari dua pertiga kebutuhan minyak dan gas mereka (Pertiwi, 2014).

Posisi perairan Indonesia menjadi penting bagi dunia juga karena wilayah perairan Indonesia digunakan sebagai jalur lalu lintas laut internasional atau yang disebut dengan Alur Laut Kepulauan Indonesia (ALKI). Selain Selat Malaka, Indonesia memiliki tiga ALKI. ALKI I merupakan alur laut dari Selat Karimata menuju Selat Sunda. Alur laut ini banyak digunakan oleh kapal dagang Cina, Jepang, dan Korea menuju Indonesia (Pelabuhan Tanjung Priok di Jakarta dan Tanjung Perak di Surabaya). ALKI II meliputi Selat Makassar ke Selat Lombok. Alur laut ini banyak digunakan oleh kapal-kapal tanker dari Eropa dan Timur Tengah ke Asia Timur. ALKI III mencakup alur kepulauan dari Sulawesi Utara-Ternate dan Pulau Seram ke Laut Arafura. Kemudian bercabang tiga: ke arah Timor Leste, ke Pulau Tanimbar, dan ke arah Pulau Kimam atau Merauke, selanjutnya ketiganya menuju Australia.

Dengan segala potensi ekonomi dari posisi strategis Indonesia, kehadiran AMF perlu dipandang sebagai upaya Indonesia dalam mengamankan sumber-sumber daya ekonomi tersebut. Dengan hadirnya AMF, negara-negara ASEAN dapat bekerja sama secara intensif dalam mengatasi berbagai ancaman terhadap keamanan maritim. Sebagai negara dengan laut terluas dan terbanyak di ASEAN serta dengan segala kekayaan dan potensi ekonomi yang dikandung oleh wilayah perairan Indonesia, terwujud-

3 Sementara tiga chokepoints lainnya adalah Selat Boshporus yang memisahkan Turki bagian Eropa dan bagian Asia serta menghubungkan Laut Marmara dengan Laut Hitam; Selat Hormuz yang memisahkan Iran dengan Uni Emirat Arab, terletak di antara Teluk Oman dan Teluk Persia; serta kawasan Laut Cina Selatan dan Laut Cina Timur. 
nya keamanan maritim merupakan kepentingan nasional Indonesia. Keamanan maritim tersebut tidak hanya terkait aspek kedaulatan akibat klaim batas laut dengan negara lain, tetapi juga terkait, misalnya, illegal fishing yang banyak merugikan Indonesia, perompakan di laut, terorisme di laut, pembajakan kapal, sampai masalah penyelundupan senjata, narkotika, dan manusia yang melalui jalur laut Indonesia.

Keamanan dan stabilitas maritim di kawasan selanjutnya menjadi kondisi yang memungkinkan Indonesia menjaga potensi ekonomi maritimnya dari berbagai ancaman. Oleh karena itu, pembentukan AMF adalah sesuatu yang rasional bagi pemerintah Indonesia di tengah dinamika ekonomi regional dan internasional. Setidaknya, harapan Indonesia dengan adanya forum ini adalah dapat membantu dalam menjaga, mengelola, bahkan melindungi potensi laut, sehingga dapat memajukan kesejahteraan bangsa dan perekonomian nasional. Jadi, untuk mencapai kepentingan dalam hal ekonomi maritim dibutuhkan kondisi keamanan maritim, dan kondisi keamanan maritim di kawasan diharapkan dapat diwujudkan melalui hadirnya AMF.

\section{AMF sebagai Realisasi Politik Luar Negeri Indonesia}

Kepentingan nasional yang dikemukakan di atas selanjutnya berusaha diwujudkan melalui implementasi politik luar negeri. Dalam hal ini, politik luar negeri Indonesia itu melahirkan inisiasi pembentukan AMF. Meskipun inisiasi pembentukan AMF lahir pada masa pemerintahan Presiden Megawati Soekarnoputri pada tahun 2003, tetapi sejak tahun 2004 hingga realisasinya tahun 2010 diperjuangkan di masa pemerintahan Presiden SBY. Dalam kaitannya dengan itu, sehingga pelaksanaan AMF perlu dilihat sebagai realisasi karakter politik luar negeri bebas-aktif dan semboyan million friends, zero enemy.

Politik luar negeri bebas-aktif telah menjadi dasar dari setiap tindakan dan kebijakan luar negeri Indonesia. Bebas dalam arti Indonesia berkomitmen untuk tidak berpihak pada salah satu kekuatan dunia, melainkan dapat bergaul dengan semua negara, serta aktif dalam arti komitmen Indonesia untuk terlibat secara aktif dalam berbagai upaya untuk memajukan dunia. Selama era SBY, prinsip bebas-aktif ini dimanifestasikan dalam semboyan million friends, zero enemy. Artinya, bahwa pemerintahan SBY berusaha untuk bergaul dan berteman baik dengan semua negara dan

\footnotetext{
4 Million friends zero enemy merupakan sebuah semboyan yang menjadi karakter dari kebijakan luar negeri Indonesia era presiden SBY. Makna dari kalimat tersebut menunjukkan bahwa Indonesia sebagai negara yang mampu menjalin kerja sama ke segala penjuru (all direction foreign policy) dalam dunia yang sedang bergejolak. Hal itu sebagaimana dianalogikan SBY melalui kiasan "navigating a turbulent ocean" (mengarungi samudra bergejolak). Semboyan tersebut memberi makna bahwa pemerintah meyakini perlunya sikap kerja sama ke semua negara tanpa menunjukkan keberpihakan, tanpa adanya musuh sekaligus pernyataan netralitas sikap Indonesia. Lihat Ziyad Falahi, (2013), "Memikirkan Kembali Arti Million Friends Zero Enemy dalam Era Paradox of Plenty," Jurnal Global \& Strategis, Th. 7, No. 2, Juli-Desember: 227-240, hal. 228-229.
} 
berupaya untuk menghindari konflik dengan negara-negara lainnya. ${ }^{4}$ Semboyan politik luar negeri itu dapat dilihat dari berbagai partisipasi dan kontribusi Indonesia di level internasional.

Dalam konteks ASEAN, upaya Indonesia untuk terus mendorong kerja sama politik dan keamanan dalam bidang maritim melalui AMF merupakan salah satu wujud realisasi semboyan tersebut. Kehadiran AMF menggambarkan upaya mengintensifkan kerja sama dalam bidang keamanan maritim. Hal ini dikarenakan keamanan wilayah maritim dipandang perlu diselesaikan secara bersama-sama antar negara. Hadirnya AMF tidak terlepas dari kondisi geopolitik Asia Tenggara yang memiliki wilayah laut yang cukup luas yakni sekitar tiga kali lipat dari luas daratan. Selain itu, kawasan ini dihuni oleh negara-negara yang berbatasan secara langsung dengan laut, kecuali Laos, dan memiliki pulau-pulau kecil sebagai bagian dari wilayah teritorialnya.

Kondisi itu mengimplikasikan dua hal bagi negara-negara Asia Tenggara. Pertama, potensi kekayaan laut yang ada memberikan keuntungan bagi negara-negara Asia Tenggara. Kedua, laut menyimpan potensi persoalan terkait klaim antar sesama negara Asia Tenggara. Masalah-masalah tersebut berpotensi mengganggu stabilitas politik dan keamanan Asia Tenggara dan kerja sama ASEAN sebagai institusi regional. Sekaitan dengan itu, Indonesia sebagai pemilik pulau terbanyak dan laut terluas di Asia Tenggara mengalami kedua hal yang dimaksud di atas.

Selain memberikan keuntungan dari sumber daya kelautan, Indonesia juga banyak terlibat konflik terkait batas dan wilayah laut dengan tetangganya, terutama karena berbatasan laut secara langsung dengan sepuluh negara. Karena itu, Indonesia memiliki kepentingan besar dalam upayaa penciptaan kerja sama regional terkait aspek maritim, meskipun orientasi politik luar negeri ke ASEAN tidaklah semata-mata menyangkut aspek maritim. Perjalanan politik luar negeri Indonesia bahkan selalu menempatkan ASEAN sebagai pilar pertama dan utama (Saputra, 2011), begitu pula sejak pemerintahan SBY yang tetap menjadikan ASEAN sebagai pilar utama politik luar negeri. Hal tersebut tersirat dalam pidato Menteri Luar Negeri RI di era SBY, Marty Natalegawa, pada Seventh General Conference of the Council for Security Cooperation in the Asia-Pacific (CSCAP), bahwa ASEAN akan tetap menjadi pilar utama dalam politik luar negeri Indonesia (Saputra, 2011).

\section{Pencapaian Kepentingan Nasional Indonesia dalam AMF}

Dalam perkembangannya sejak 2010, AMF mengalami perluasan keanggotaan menjadi Expanded-AMF (EAMF). Jika AMF melibatkan sepuluh negara ASEAN, maka EAMF memasukkan pula delapan negara Mitra Wicara ASEAN yang juga merupakan anggota East Asia Summit (EAS): AS, 
Australia, Cina, India, Jepang, Korea Selatan, Rusia, dan Selandia Baru. Perluasan keanggotaan ini adalah pencapaian penting Indonesia saat menjadi Ketua ASEAN pada tahun 2011. Ketika menjadi Ketua ASEAN 2011, dalam pertemuan AMF ke-2 di Thailand, Indonesia mengusulkan penguatan kerja sama AMF melalui perluasan keanggotaan (Oratmagun, 2012). Usulan tersebut kemudian disambut baik dan diterima para pemimpin negara-negara ASEAN pada KTT ke-19 di Bali, pada 17 November 2011 (Direktorat Jenderal Kerja Sama ASEAN, 2015). Hal ini memberi makna pada komitmen Indonesia untuk million friends, zero Emmy di masa itu.

Lebih lanjut, ketika kembali menjadi tuan rumah pada pertemuan ke-6 AMF di Manado pada tahun 2016, Indonesia mengangkat pentingnya penanggulangan isu Illegal, Unregulated, Unreported (IUU Fishing). Indonesia mengusulkan perlunya pengembangan pengaturan regional penanggulangan IUU Fishing dan menggalang dukungan mengenai isu tersebut (Yusilawati, 2016). Bagi Indonesia, pembahasan dan perhatian negara-negara ASEAN terkait IUU Fishing ini penting karena mengancam keberlangsungan lingkungan laut, sumber daya pangan, keamanan, dan kedaulatan Indonesia. Apalagi Indonesia merupakan negara produsen ikan terbesar pertama di kawasan Asia Tenggara. Produksi ikan Indonesia bisa mencapai 5,4 juta ton setiap tahun, yang sekaligus menyumbang sekitar $11 \%$ dari total seluruh produksi ikan di kawasan Asia Pasifik di mana sejak tahun 2006 kawasan ini menyumbang produksi ikan dunia sebesar 50 \% (Amri, 2016).

Karena itu, Indonesia memandang IUU Fishing sebagai kejahatan serius yang harus diberantas bersama. Berdasarkan paparan data Chaniago (2016), setiap tahun Indonesia mengalami kerugian hingga 20 triliun akibat tindakan penangkapan ikan secara ilegal ini. Sejalan dengan itu, kasus-kasus IUU Fishing ini umumnya melibatkan armada atau kapal asing (foreign fishing fleet atau FFF). Data Kementerian Perikanan dan Kelautan menunjukkan bahwa jumlah armada asing yang melakukan IUU Fishing mengalami dinamika setiap tahun. Tahun 2005, terdapat 24 FFF yang melakukan IUU Fishing kemudian meningkat menjadi 124 pada tahun 2008, bahkan hingga tahun 2010 meningkat secara signifikan menjadi 159 (Septaria, 2016). Meski sempat menurun pada pada tahun 2011, tapi kemudian pada tahun 2015 bertambah kembali menjadi 194 kasus FFF. Menurut Septaria (2016), hal ini menunjukkan bahwa perairan Indonesia merupakan kawasan yang sangat mudah terjadi praktik IUU Fishing. Masalah ini setidaknya dapat dipahami karena Indonesia memiliki perairan yang sangat luas dan "banyak pintu" sehingga secara keseluruhan tidak dapat dikontrol.

Sayangnya, usulan Indonesia mengenai perlunya pembentukan instrumen mengikat dalam upaya menangani IUU Fishing ternyata tidak sepenuhnya memperoleh dukungan negara-negara anggota ASEAN. Alasannya, terdapat perbedaan kepentingan dan perbedaan pemahaman yang 
mendasar mengenai IUU Fishing di ASEAN. Bahkan beberapa negara disebut menolak secara terang-terangan usulan Indonesia karena khawatir adanya instrumen regional terkait pemberantasan IUU Fishing dapat berdampak negatif terhadap perekonomian mereka (Yusilawati dan Chaniago, 2016). Pasalnya dalam kasus IUU Fishing yang terjadi di perairan Indonesia, pelakunya banyak melibatkan kapal dari negara-negara tetangga Indonesia. Negara-negara Asia Tenggara yang terjerat kasus IUU Fishing secara berurutan adalah Malaysia, Filipina, Thailand, dan Vietnam, sedangkan negara di luar kawasan Asia Tenggara adalah Cina dan Papua Nugini (Septaria, 2016).

Selain itu, negara-negara ASEAN memiliki perbedaan pandangan terkait illegal fishing sebagai kejahatan (Yusilawati dan Chaniago, 2016). Padahal IUU Fishing jelas merupakan sebuah kejahatan. Laporan United Nation Office on Drugs and Crime (UNODC) bahkan menyebut IUU Fishing dalam banyak kasus terbukti berkaitan dengan dengan kegiatan kelompok kejahatan transnasional, seperti pencucian uang, korupsi, perdagangan manusia dan narkoba, serta penyelundupan manusia. Akibatnya, Indonesia memutuskan untuk berupaya mendorong pembentukan instrumen yang mengikat mengenai IUU Fishing di luar mekanisme ASEAN.

Dalam hal ini, dapat dikatakan bahwa kepentingan nasional Indonesia melalui AMF belum sepenuhnya tercapai. Mengingat IUU Fishing adalah isu yang dianggap urgen dan sekaligus mendesak bagi Indonesia, faktanya, usulan untuk lahirnya peraturan hukum di ASEAN yang bersifat mengikat belum memperoleh dukungan semua negara ASEAN. Sementara itu, kepentingan yang terkait IUU Fishing bukan hanya terkait dimensi ekonomi dari kekayaan dan potensi kelautan, tetapi juga menyangkut kepentingan vital (core) yakni soal kedaulatan negara dan integritas teritorial.

Penyelenggaraan AMF ke-7 tahun 2016 yang seharusnya dilaksanakan di Brunei Darussalam tidak terlaksana dan tidak ada negara lain yang bersedia menjadi tuan rumah. Pada akhirnyaa, dengan dukungan Filipina, AMF ke-7 tahun 2017 dilaksanakan oleh Indonesia di Sekretariat ASEAN, Jakarta. Dalam hal ini, terdapat indikasi bahwa negara-negara ASEAN tidak sepenuhnya berkomitmen penuh dalam AMF, dan AMF tidak sepenuhnya menjadi agenda yang menjadi fokus perhatian negara-negara ASEAN. Muhibat (2017) bahkan mengatakan bahwa dalam kasus tersebut, masa depan AMF/EAMF berada ketidakpastian (uncertainty).

Muhibat (2017) dalam analisisnya mengajukan pertanyaan "Does this imply that only a couple of ASEAN states are still eager to hold the related regional maritime forums?" Apakah hal tersebut menunjukkan hanya ada dua negara, yakni Indonesia dan Filipina yang sangat bersemangat untuk hadirnya forum maritim di kawasan? Mengingat hanya keduanya yang merupakan 
negara kepulauan dengan jumlah pulau yang banyak, yakni Indonesia sebanyak 17.504 dan Filipina sebanyak 7.107 pulau, sehingga punya kepentingan strategis terhadap berbagai isu maritim.

Hal itu diakui pula oleh Kementerian Luar Negeri bahwa tujuan AMF untuk menyinergikan berbagai kerja sama maritim di ASEAN belum sepenuhnya tercapai (Yusilawati, 2016). Alasannya karena belum semua perwakilan dari badan sektoral ASEAN dapat hadir, di mana tidak semua delegasi dari masing-masing negara anggota ASEAN mewakili badan sektoralnya. Hal ini tidak terlepas pula dari bentuk organisasional AMF yang hanya sebatas forum dialog yang tidak memiliki instrument of power untuk negara-negara anggota.

Lebih lanjut lagi, Muhibat (2017) menyatakan bahwa terdapat masalah dalam format organisasional AMF. Process-oriented dan basis organisasional AMF mengikuti praktik umum di ASEAN, tanpa adanya aktivitas berbasis program yang terencana secara sistematis. Implikasinya, dalam EAMF misalnya, bisa jadi agenda-setting dapat didorong oleh negara-negara non-ASEAN, terutama oleh negara yang ingin memberikan bantuan sumber pendanaan. Dengan demikian, dapat dikatakan bahwa meski inisiasi dan pembentukan AMF sarat dengan kepentingan Indonesia, namun AMF sendiri belum sepenuhnya dapat menjadi wadah bagi pencapaian kepentingan nasional Indonesia terkait isu-isu maritim.

\section{Kesimpulan}

Argumen utama tulisan ini adalah bahwa pembentukan AMF sebagai kerangka kerja sama ASEAN terkait isu dan masalah maritim tidak terlepas dari kepentingan nasional Indonesia. Indonesia adalah negara dominan di kawasan dalam hal laut, sehingga kebijakan Indonesia di tataran regional tidak dapat dilepaskan pula dari aspek kelautan. Dalam hal ini kepentingan Indonesia dalam mengajukan pembentukan AMF didasarkan pada, pertama, Indonesia adalah negara kepulauan terbesar bukan hanya di kawasan tetapi juga di dunia. Identitas fisik itu tidak terlepas pula dari sejarah kejayaan maritim di masa lalu. Hadirnya AMF kemudian menjadi penegasan tentang kepentingan Indonesia berkaitan dengan identitasnya sebagai Archipelagic State.

Kedua, identitas sebagai negara kepulauan menjadi justifikasi dari kepentingan Indonesia terkait kedaulatan dan integritas wilayah laut. Sebagai negara kepulauan yang luas, ancaman terhadap keamanan maritim menjadi penting bagi Indonesia. Hadirnya AMF selanjutnya dapat menjadi arena bagi Indonesia untuk mencapai kepentingannya dalam menjaga kedaulatan maritim dari ancaman, baik dari sengketa perbatasan laut dengan tetangga maupun dari ancaman kejahatan aktor-aktor non negara. 
Ketiga, penciptaan keamanan maritim itu juga tidak terlepas dari kepentingan ekonomi maritim Indonesia. Potensi pemasukan negara dari sumber daya laut dan modalitas laut cukup besar. Hadirnya AMF yang salah satu tujuannya sebagai forum pembahasan berbagai ancaman keamanan maritim di kawasan dipandang akan memberikan keuntungan bagi Indonesia. Keuntungan yang dimaksud terkait dalam hal menjaga dan mengamankan segala potensi ekonomi yang berdasar pada laut untuk pembangunan dan kesejahteraan bangsa.

Meskipun pembentukan AMF sarat dengan kepentingan Indonesia, AMF belum sepenuhnya dapat menjadi wadah bagi pencapaian kepentingan nasional tersebut. Terkait upaya penanganan IUU Fishing yang menjadi kepentingan strategis karena berkaitan dengan kedaulatan dan ekonomi maritim, misalnya, Indonesia belum bisa menjadikan AMF sebagai instrumen ASEAN untuk menyepakati perlunya kerangka hukum dan aturan tentang IUU Fishing. Usulan Indonesia terkait perlunya penanganan IUU Fishing secara regional melalui lahirnya aturan ASEAN belum disetujui oleh negara-negara ASEAN lainnya. Selain itu, dinamika pelaksanaan AMF seolah menunjukkan minimnya komitmen negara-negara ASEAN terhadap AMF.

Kajian ini selanjutnya dapat memberikan kontribusi dan implikasi pada studi tentang rezim internasional. Bahwa, sekalipun rezim internasional tidak dapat dilepaskan dari adanya kepentingan suatu negara, namun hadirnya rezim internasional tidak selalu dapat menjadi instrumen bagi pencapaian kepentingan nasional negara tersebut. Selain itu, kajian ini menambah khasanah terkait politik luar negeri di kawasan Asia Tenggara, di mana Indonesia menegaskan ASEAN sebagai soko guru politik luar negerinya.

\section{Ucapan Terima Kasih}

Ucapan terima kasih penulis sampaikan kepada Direktorat Penelitian dan Pengabdian kepada Masyarakat (DPPM) serta Fakultas Ilmu Sosial dan Ilmu Politik Universitas Muhammadiyah Malang yang telah mendanai penelitian ini melalui skim penelitian dana langsung (block grant) fakultas.

\section{Daftar Pustaka}

Adisasmita, R. (2013). Pembangunan Ekonomi Maritim. Yogyakarta: Graha Ilmu

Amri, A. A. (201 6). Maritime Security Challenges in Southeast Asia: Analysis ofInternational and Regional Legal Frameworks, Thesis Doctor of Philosophy, University of Wollongong.

Arsana, I.M \& Sumaryo. (2010). Aspek Geospasial Batas Maritim Interna- 
sional Indonesia dalam Pengelolaan Wilayah Perbatasan. Dalam: Madu, L. et. al,. eds. Mengelola Perbatasan Indonesia di Dunia Tanpa Batas: Isu, Permasalahan dan Pilihan. Yogyakarta: Graha Ilmu.

Ayu, N. C. (2015). Telaah Strategi Indonesia dalam Pengamanan Selat Malaka. Dalam: Susilo, I. B. Kemaritiman Indonesia: Problem Dasar Strategi Maritim Indonesia. Surabaya: CSGS

Bradford, J. F. (2005). The Growing Prospects for Maritime Security Cooperation in Southeast Asia. Naval War College Review, 58 (3) pp. 63-86.

Chaniago, R. J. (2017) Testing The Water Penguatan Kerja Sama Penanganan IUU Fishing Melalui ASEAN Regional Forum (ARF) [Online], Masyarakat ASEAN. Tersedia di: <https://www.kemlu. go.id/Majalah/ASEAN20Edisi\%2014\%202017.pdf> [diakses 11 Desember 2017]

Direktorat Jenderal Kerja Sama ASEAN. (2015). ASEAN Selayang Pandang, Cet Ke-21 Tahun 2015. Jakarta: Ditjen Kerja Sama ASEAN Kementerian Luar Negeri RI.

Falahi, Z. (2013). Memikirkan Kembali Arti Million Friends Zero Enemy dalam Era Paradox of Plenty. Jurnal Global \& Strategis, 7(2), pp. $227-240$

Gaol, T. L. (2017). Peran ASEAN Maritime Forum (AMF) dalam Menjaga Keamanan Maritim (Studi Kasus Perompakan di Perairan Selat Malaka). Jom FISIP , 4 (1), pp. 1-9.

Holsti, K. J. (1987). Politik Internasional, Kerangka Analisa. Jakarta: Pedoman Ilmu Jaya.

Kartinawati. (2013). Peran ASEAN Maritime Forum (AMF) dalam Keamanan Perairan di Asia Tenggara. eJournal Ilmu Hubungan Internasional, 1(3), pp. 715-730.

Kementerian Luar Negeri RI. (2010) 1st Meeting Of Asean Maritime Forum (AMF) [Online], 7 Februari. Tersedia di:<http://www.kemlu.go.id/ en/berita/siaran-pers/Pages/1st-Meeting-Of- Asean-Maritime-Forum-AMF.aspx> [diakses pada 8 Februari 2017].

Kemenerian Luar Negeri Indonesia. (2011). Diplomasi Indonesia 2010. Jakarta: Kementerian Luar Negeri RI.

Kementerian Luar Negeri Indonesia. (2017) Para Pejabat Senior Mempersiapkan KTT ke-30 ASEAN di Manila [Online], 27 April. Tersedia di: $<$ https://www.kemlu.go.id/id/berita/Pages/Para-Pejabat-SeniorMempersiapkan-KTT-Ke-30-ASEAN-di-Manila.aspx> [diakses 22 November 2017].

Kusumastanto, T. (2013). Pemberdayaan Sumberdaya Kelautan, Perikanan dan Perhubungan Laut dalam Abad XXI [Online], 21 Januari. Tersedia di: <http://perpustakaan.bappenas.go.id/lontar/file?file=digital/143768- [_Konten_]-Konten\%20D139.pdf> [diakses 8 Novem- 
ber 2017].

Limbong, B. (2015). Poros Maritim. Jakarta: Margaretha Pustaka.

Luhulima, CPF., et al,. (2008). Masyarakat Asia Tenggara Menuju Komunitas ASEAN 2015. Yogyakarta: Pustaka Pelajar.

Masyarakat ASEAN. (2016). Membangun Kiprah Maritim Indonesia di Kawasan. Edisi 14, Desember 2016.

Morgenthau, H. J. (2010). Politik Antarbangsa. Jakarta: Yayasan Pustaka Obor Indonesia.

Muhibat, S. F. (2017). AMF and EAMF: A Uncertain Future? RSIS Commentary, No. 111, 2 Juni 2017.

Oratmagun, D. (2012) Fokus Indonesia Selama Keketuaan 2011 [Online], Tabloid Diplomasi, 20 Februari. Tersedia di:<http://www.tabloiddiplomasi.org/index.php/2012/02/20/fokus-indonesia-selama-keketuaan-2011-adalah-memastikan-kemajuan si gnifik a n - d a lam-pencapaian-komunitas-asean/> [akses 20 November 2017].

Parlementaria. (2014). Majalah Dewan Perwakilan Rakyat Republik Indonesia, Edisi 119.

Pertiwi, S. B. (2014). Analisis Kekuatan Maritim sebagai Komponen Utama Hard Power Indonesia di Era Presiden Joko Widodo. Makalah dipresentasikan di Konvensi Nasional Asosiasi Ilmu Hubungan Internasional Indonesia, Universitas Budi Luhur Jakarta.

Plano, J. C. \& Olton, R. (1999). Kamus Hubungan Internasional. Bandung: Putra A Bardin.

Prasetia, A. (2016). Ekonomi Maritim Indonesia. Yogyakarta: Diandra Kreatif.

Salamah, L. (2016). Strategi Peningkatan Ekonomi Negara Maritim Indonesia dalam Perspektif Global, Vol. 7. Makalah dipresentasikan di Konvensi Nasional Asosiasi Ilmu Hubungan Internasional: Benua Maritim Indonesia Dalam Perspektif Ilmu Hubungan Internasional, Universitas Hasanuddin.

Saputra, A. B. (2011) Politik Luar Negeri Indonesia di Bawah Susilo Bambang Yudhoyono Tahun 2009-2011 [Online], 20 September. Tersedia di: $\quad<$ http://repository.unri.ac.id/xmlui/bitstream/handle/123456789/1066/PLN\%20RI\%20Era\%20Presiden\%20SBY\%20 2009-2011.pdf?sequence $=1>$ [diakses pada 8 November 2017].

Sekretariat Nasional ASEAN-Indonesia. (2017) Wamenlu Dr. A.M. Fachir Tegaskan Pentingnya ASEAN Atasi Tantangan Kejahatan di Laut [Online], 6 Desember. Tersedia di: <http://setnas-asean.id/siaran-pers/ $\mathrm{read} /$ wamenlu-dr-a-m-fachir-tegaskan-pentingnya-asean-atasi-tantangan-kejahatan-di-laut> [diakses 8 Februari 2017].

Septaria, E. (2016). IUU Fishing In Indonesia, Are Asean Member States Responsible For? International Journal of Business, Economics and Law, 11(4), pp. 76-85. 
Tabloid Diplomasi. (2010) ASEAN Maritime Forum (AMF) [Online], 4 Agustus.Tersedia di:<http://www.tabloiddiplomasi.org/previous-isuue/104-agustus-2010/904-asean-maritime-forum-amf.htm> [diakses 8 Februari 2017].

Tabloid Diplomasi. (2010) Konsep Pembentukan ASEAN Maritime Forum [Online], 10 Agustus. Tersedia di:<http://www.tabloiddiplomasi. org/previous-isuue/104-agustus-2010/902- konsep-pembentukan-asean-maritime-forum.html> [diakses 8 Februari 2017].

Wibowo, T. (2010) ASEAN Maritime Forum Akan Dapat Mengatasi Berbagai Isu Terkait Wilayah Maritim [Online], Tabloid Diplomasi, 10 Agustus. Tersedia di: <http://www.

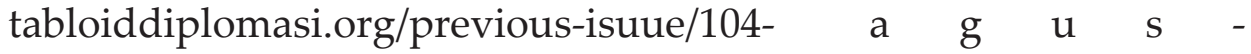
tus-2010/903-asean-maritime-forum-akan-dapat-mengatasi- b e r b agai-isu-terkait-wilayah-maritim.html> [diakses pada 8 Februari 2017].

Yusilawati, D. \& Chaniago, R. J. (2016). Menciptakan Kawasan Bebas IUU Fishing di ASEAN, Masyarakat ASEAN, Edisi 12. 